\title{
De arbeidsmarkt naar beroep in 1992 en de positie van academici daarbinnen
}

Citation for published version (APA):

de Grip, A., Heijke, J. A. M., Dekker, R., \& Groot, L. F. M. (1987). De arbeidsmarkt naar beroep in 1992 en de positie van academici daarbinnen. Researchcentrum voor Onderwijs en Arbeidsmarkt, Faculteit der Economische Wetenschappen. ROA Working Papers No. 1 https://doi.org/10.26481/umarow.1987001

Document status and date:

Published: 01/01/1987

DOI:

10.26481/umarow.1987001

Document Version:

Publisher's PDF, also known as Version of record

\section{Please check the document version of this publication:}

- A submitted manuscript is the version of the article upon submission and before peer-review. There can be important differences between the submitted version and the official published version of record.

People interested in the research are advised to contact the author for the final version of the publication, or visit the DOI to the publisher's website.

- The final author version and the galley proof are versions of the publication after peer review.

- The final published version features the final layout of the paper including the volume, issue and page numbers.

Link to publication

\footnotetext{
General rights Owners
rights.

- You may freely distribute the URL identifying the publication in the public portal. please follow below link for the End User Agreement:

www.umlib.nl/taverne-license

Take down policy

If you believe that this document breaches copyright please contact us at:

repository@maastrichtuniversity.nl

providing details and we will investigate your claim.
}

Copyright and moral rights for the publications made accessible in the public portal are retained by the authors and/or other copyright owners and it is a condition of accessing publications that users recognise and abide by the legal requirements associated with these

- Users may download and print one copy of any publication from the public portal for the purpose of private study or research.

- You may not further distribute the material or use it for any profit-making activity or commercial gain

If the publication is distributed under the terms of Article $25 \mathrm{fa}$ of the Dutch Copyright Act, indicated by the "Taverne" license above, 
DE ARBEIDSMARKT NAAR BEROEP IN 1992

EN DE POSITIE VAN ACADEMICI

DAARBINNEN.

ROA-W-1987/1

A. de Grip, J.A.M. Heijke,

R.J.P.Dekker, L.F.M. Groot

Researchcentrum voor Onderwijs en Arbeidsmarkt

Faculteit der Economische Wetenschappen

Rijksuniversiteit Limburg

Maastricht, december 1987 
s. 


\section{VERANTWOORDING}

Het onderzoek waarover hier wordt gerapporteerd is uitgevoerd binnen het kader van een meerjarige onderzoeksopdracht van het Ministerie van Onderwijs en Wetenschappen. Deze opdracht betreft de ontwikkeling van een informatie-systeem onderwijs-arbeidsmarkt, dat bruikbaar is voor de school- en beroepskeuze van leerlingen in het voortgezet en hoger onderwijs (ROA 1987). Het onderzoek is mede mogelijk gemaakt door een aanvullende onderzoeksopdracht in het kader van het project I-SEE, dat door het Centrum voor Beleidsanalyse en Advies te Nijmegen wordt uitgevoerd in opdracht van de Interdepartementale Stuurgroep Studie- en Beroepskeuze Voorlichting. Het I-SEE project betreft de ontwikkeling van een geautomatiseerd school- en beroepskeuzesysteem. Het systeem zal uit verschillende modules bestaan. Het ROA heeft gegevens verschaft ten behoeve van de bouw van de zogenaamde arbeidsmarktmodule (De Grip, Heijke, Dekker, Groot en Vos 1987).

Deze discussienota moet worden gezien als de eerste versie van een vooralsnog onvolledig informatiesysteem onderwijs-arbeidsmarkt. Dit systeem kon in korte tijd worden ontwikkeld door relatief eenvoudige kwantitatieve (prognose)methoden toe te passen op direct bruikbare statistische basisgegevens en door - waar mogelijk - uit te gaan van reeds door anderen gemaakte prognoses. De verdere ontwikkeling van het systeem zal globaal gesproken neerkomen op een verdere verbetering en uitbreiding van de gebruikte statistische basisgegevens, de toegepaste methoden en van de benutting van de prognosegegevens op deelterreinen van de arbeidsmarkt.

Het onderzoek stond onder leiding van prof. dr. J.A.M. Heijke, directeur van het ROA. De dagelijkse leiding berustte bij dr. A. de Grip. Aan het onderzoek is verder meegewerkt door drs. R.J.P. Dekker en drs L.F.M. Groot. L.A. Vos verleende assistentie bij het verwerken van het data-materiaal. 
INHOUD

pag

1. Inleiding 3

2. Werkgelegenheidsprognoses 9

2.1 Inleiding 9

2.2 Bedrijfssectoren 9

2.3 Beroepsklassen 12

2.4 Academische studierichtingen 18

3. Vervangingsvraag 22

3.1 Inleiding 22

3.2 Vervangingsvraag per beroepsklasse 22

3.3 Vraag naar 'schoolverlaters' per beroepsklasse 23

3.4 Vervangingsvraag naar academische studierichting 28

4. De arbeidsmarktsituatie naar academische studierichting 30

5. Enkele risico indicatoren 33

5.1 Inleiding 33

5.2 Werkgelegenheidsfluctuaties in beroepsklassen 33

5.3 Branchespreiding van beroepsklassen 35

5.4 Beroepenspreiding van academische studierichtingen 37

6. Arbeidsmarktperspectieven 39

$\begin{array}{ll}6.1 \text { Inleiding } & 39 \\ 6.2 \text { Perspectieven van beroepsklassen } & 39 \\ 6.3 \text { Perspectieven van academische studierichtingen } & 45\end{array}$

7. Besluit 48

Literatuur $\quad 49$ 
1. INLEIDING

Voor het goed functioneren van de arbeidsmarkt is het belangrijk dat jongeren bij hun studiekeuze rekening houden met de situatie op de arbeidsmarkt. Uit verschillende enquete-onderzoeken blijkt dat dit in de praktijk ook veelal het geval is (zie b.v. Kodde 1984 en De Grip 1984). Weliswaar gaat het daarbij niet primair om het maximaliseren van het in de toekomst te verdienen inkomen, zoals de human-capital theorie min of meer veronderstelt, maar veeleer om het streven naar een goede kans op het vinden van een baan.

Het gevaar doet zich echter voor dat men, vanwege het ontbreken van informatie over de toekomstige arbeidsmarktsituatie, zich moet baseren op de situatie op de arbeidsmarkt op het moment waarop men aan een studie begint. Dit kan immers leiden tot een overreactie op bestaande tekorten of overschotten op bepaalde arbeidsmarktsegmenten, waardoor zgn. 'varkenscycli' kunnen optreden (zie De Grip 1987).

Prognoses van de arbeidsmarktsituatie op het moment waarop degenen die nu een studie kiezen, instromen op de arbeidsmarkt zouden dergelijke overreacties mogelijk kunnen temperen, omdat in deze prognoses al rekening kan worden gehouden met het aantal toekomstige schoolverlaters dat nu reeds 'in de pijplijn' van het onderwijs zit.

Met name in de jaren ' 60 kenden arbeidsmarktprognoses een grote populariteit. Het ging daarbij vooral om werkgelegenheidsprognoses die werden opgesteld op basis van de zgn. 'Manpower Requirements Approach' (zie b.v. Hollister 1965). Bij deze methode worden achtereenvolgens de volgende stappen gezet:

1 - Er wordt een prognose gemaakt van de macro-economische ontwikkeling ;

2 - Mede op basis hiervan wordt de ontwikkeling van de sectorale productie geprognosticeerd;

3 - Op basis van de verwachte ontwikkeling van de sectorale arbeids produktiviteit wordt een prognose gemaakt van de werkgelegenheid in de diverse bedrijfssectoren; 
4 - Er van uit gaande dat de beroepenstructuur van de verschillende sectoren ongewijzigd blijft, wordt een raming gemaakt van de werkgelegenheid in de diverse beroepen.

5 - Wanneer ook de opleidingsstructuur van de beroepen ongewijzigd blijft, kan tenslotte een prognose worden gemaakt van de behoefte aan arbeidskrachten naar de verschillende opleidingniveaus en -richtingen.

Vaak wordt daarbij de vierde stap overgeslagen; op basis van de sectorale werkgelegenheidsprognoses wordt dan direct een raming gemaakt van de opleidingsbehoefte (zie Youdi \& Hinchcliffe 1985).

Los van de onzekerheid waarmee de macro- en meso-economische prognoses vanzelfsprekend zijn omgeven, gaat de belangrijkste kritiek op deze aanpak uit naar de mechanische wijze warop de sectorale werkgelegenheid wordt verbijzonderd naar beroepsgroepen en opleidingen.

Deze aanpak veronderstelt dat de substitueerbaarheid van arbeidskrachten met een verschillend beroep en/of opleiding nihil is. Voor wat betreft de omrekening van de werkgelegenheid in een bepaald beroep naar de behoefte aan schoolverlaters met een bepaalde opleiding wordt bovendien verondersteld dat er sprake is van een eenduidige relatie tussen het beroep en de daarvoor benodigde opleiding. Blaug merkt hierover op (1967, p. 281) : "And here the real problem is not simply the failure to observe any unique relationship between educational background and occupational affiliation in to-day's labour force, except for those professions such as medicine and teaching where custom imposes a minimum entrance qualification, but the difficulty of separating the forces of supply from the forces of demand. What we have here is the old 'identification problem'. After all, the schooling currently associated with each occupation is as much the outcome of the supply of educated people in the past as of the history of the demand for qualified manpower. In any economy with a high level of aggregate demand qualified manpower, however irrationally produced, will somehow be absorbed into employment : what we observe to-day may simply represent the misallocations of the past". 
Van Hoof en Dronkers (1980) bestempelen de veronderstelde directe relatie tussen een beroep en een bepalde opleiding als het "naieve model" van de arbeidsmarkt. De in de praktijk doorgaans veel flexibelere relatie tussen beroepen en opleidingen wordt door hen als een belangrijke oorzaak gezien van het niet uitkomen van veel manpower-prognoses.

In een prognose-studie van het NEI (1986) is geprobeerd rekening te houden met deze kritiek, door ontwikkelingen van de beroepenstructuren van bedrijfssectoren en de opleidingsstructuren van beroepen naar de toekomst te extrapoleren. Deze aanpak veronderstelt dat toekomstige ontwikkelingen, waaronder de aanpassingsprocessen op de arbeidsmarkt, zich qua aard en omvang op dezelfde wijze en met dezelfde gevolgen voordoen als in het nabije verleden.

Bij een recente prognose van de werkgelegenheid naar verschillende opleidingscategorieen van het CPB (1987-II) is getracht verklarende factoren aan te dragen voor de verschuiving van de opleidingsstructuren van bedrijfstakken, om op basis daarvan werkgelegenheidsramingen te maken, waarin rekening wordt gehouden met de veranderingen die voortvloeien uit de gevonden verklaringsgronden.

Er worden in deze CPB-prognose slechts vier opleidingsniveaus onderscheiden (basisonderwijs, LBO/MAVO, HAVO/VWO/MBO en HBO/WO) en maar vier opleidingsrichtingen (algemeen vormend, technisch, economisch/administratief en verzorgend). De opzet is dus veel te globaal om bruikbaar te kunnen zijn voor de studie- en beroepskeuze of de onderwijsplanning.

In de onderhavige studie is er naar gestreefd arbeidsmarktprognoses op te stellen voor meer specifieke opleidingsrichtingen binnen het wetenschappelijk onderwijs in ons land. Daarbij zijn twalf studierichtingen onderscheiden. Een dergelijke verdergaande desaggregatie bergt het gevaar in zich dat de voorspellingen een grotere kans hebben niet uit te komen dan minder gedifferentieerde ramingen. Immers, in het laatste geval is de kans groter dat eventuele voorspelfouten elkaar zullen compenseren. Bovendien zal een deel van de toekomstige verschuivingen in de opleidingsstructuur zich binnen deze globale opleidingsrichtingen afspelen. In deze studie is geprobeerd dit dilemma tussen enerzijds kwalitatief betere, maar meer globale prognoses en anderzijds voor de studieen beroepskeuze meer relevante, maar mogelijk kwalitatief mindere prog- 
noses te doorbreken, door geen exacte 'punt'-voorspellingen te doen, maar een richtinggevende kwalitatieve aanduiding te geven van de werkgelegenheidsvooruitzichten (goed, slecht, e.d.).

Hoewel in deze studie uiteindelijk is toegewerkt naar prognoses voor de academische studierichtingen, zal tevens worden ingegaan op de hieraan ten grondslag liggende voorspellingen voor (alle) 82 beroepsklassen. In tegenstelling tot de opleidingen die zich zoals gezegd beperken tot het universitaire onderwijs, wordt bij de beroepenprognoses wel een totaalbeeld gegeven van de verwachte ontwikkelingen.

Daarnaast wordt nog additionele informatie verstrekt over de werkgelegenheidsrisico's die aan de uitoefening van verschillende beroepen en aan het volgen van verschillende academische studierichtingen zijn verbonden. Bij de beroepen is hierbij gekeken naar de mate waarin de werkgelegenheid fluctueert en naar de branchespreiding van een beroepsklasse. Het laatste geeft een indicatie van de uitwijkmogelijkheden naar andere sectoren die er binnen een beroep bestaan. Voor de verschillende studierichtingen is een soortgelijke indicator geconstrueerd voor de beroepenspreiding (ook hier een indicatie van de flexibiliteitsmogelijkheden).

Het afstemmen van studiekeuzebeslissingen op de arbeidsmarkt vindt plaats in een situatie van onzekerheid. Het gaat er om deze onzekerheid te verminderen door degene die moet beslissen zo goed mogelijk informatie te geven over de factoren die bij deze beslissingen een rol kunnen spelen. Het is in dit kader dat wij naast een kwalitatieve prognose van de arbeidsmarktsituatie op het moment waarop men kan afstuderen, ${ }^{1}$ ook informatie verstrekken over de uitwijkmogelijkheden met een bepaalde studie, of in een bepaald beroep en over de conjunctuurgevoeligheid van de verschillende beroepen.

1) Voor degenen die in 1988 aan een universitaire studie beginnen is dit 1992 . 
Vooralsnog doen zich daarbij enkele belangrijke beperkingen voor met betrekking tot het beschikbare datamateriaal. Er is gebruik gemaakt van de Arbeidskrachtentellingen van het CBS, die slechts beschikbaar zijn voor de oneven jaren in de periode 1975-1985 (De opleidingscijfers alleen voor de jaren 1979-1985). Daarnaast leveren de data van de beroepen (de 2-digit niveau 'beroepsklassen') vanuit het oogpunt van de studieen beroepskeuze belangrijke tekortkomingen. ${ }^{2}$

De verdere opzet van deze studie is als volgt. In hoofdstuk 2 wordt achtereenvolgens ingegaan op de werkgelegenheidsprognoses naar bedrijfssectoren (paragraaf 2.2), bedrijfsklassen (paragraaf 2.2) en studierichtingen (paragraaf 2.3). Daarna wordt in hoofdstuk 3 aandacht besteed aan de voorspellingen van de vervangingsvraag voor de verschillende beroepsklassen (paragraaf 3.2 ), de vraag naar schoolverlaters per beroepsklasse (paragraaf 3.3 ) en de vervangingsvraag per studierichting (paragraaf 3.4).

In hoofdstuk 4 volgt een beschrijving van de arbeidsmarktsituatie naar studierichting. Eerst wordt aandacht besteed aan de vraag naar nieuwkomers tussen 1985 en 1992. Vervolgens wordt ingegaan op het aanbod van afstuderenden in deze periode, waarna tenslotte een typering volgt van de arbeidsmarktsituatie voor de twalf academische studierichtingen in 1992.

In hoofdstuk 5 komen de bovengenoemde risico indicatoren aan de orde. Achtereenvolgens wordt ingegaan op de werkgelegenheidsfluctuaties (paragraaf 5.2) en de branchespreiding van beroepsklassen (paragraaf 5.3) en op de beroepenspreiding van de verschillende studierichtingen (paragraaf 5.4 ).

2) In De Grip, Groot en Heijke (1987) is geprobeerd hiervoor een oplossing aan te dragen. 
Vervolgens wordt in hoofdstuk 6 een algehele typering gegeven van de arbeidsmarktperspectieven van de verschillende beroepsklassen (paragraaf 6.2) en studierichtingen (paragraaf 6.3). Het betreft hier de eerder genoemde kwalitatieve informatie die uiteindelijk aan de studiekeuzebeslisser zou moeten worden verstrekt. Het in de voorgaande hoofdstukken gepresenteerde datamateriaal kan hierbij eventueel als achtergrondinformatie worden gebruikt. Tenslotte worden in hoofdstuk 7 nog enkele evaluerende opmerkingen gemaakt. 


\section{WERKGELEGENHEIDSPROGNOSES}

\section{$\underline{2.1}$ Inleiding}

In dit hoofdstuk wordt een beschrijving gegeven van de wijze waarop de prognoses van de werkgelegenheid naar beroepsklassen en studierichtingen in 1992 tot stand zijn gekomen. De voorspellingen worden gedaan in een drietal stappen. Eerst wordt een raming gemaakt van de werkgelegenheid in de verschillende bedrijfssectoren. Deze bedrijfstakprognoses dienen vervolgens als "basis voor de werkgelegenheidsprognoses voor de beroepsklassen. Op hun beurt zijn deze laatste prognoses weer het uitgangspunt voor de voorspellingen naar studierichting. In de volgende drie paragrafen wordt achtereenvolgens op deze drie stappen in de prognose methodisch ingegaan.

\subsection{Bedrijfssectoren}

De eerste stap bij het maken van de werkgelegenheidsprognoses voor 1992 vormen de sectorale prognoses. Hiervoor is aansluiting gezocht bij de middellange-termijn raming van het CPB (1986). Tabel 1 laat enkele veronderstellingen zien, die aan deze prognoses ten grondslag hebben gelegen. Het merendeel van deze veronderstellingen heeft betrekking op de internationale concurrentiepositie van het bedrijfsleven.

Tabe1 1: Veronderstellingen middellange-termijn prognose CPB

\section{Veronderstellingen}

Volume wereldhandel (ongewogen)

Concurrerende uitvoer

Prijspeil goedereninvoer (in gld.)

Concurrerend uitvoerprijspeil (in gld.)

Loonkosten per eenheid produkt in

de verwerkende industrie in het buitenland

Effectieve koers van de gulden

t. o.v. concurrenten op buitenlandse markten

t.o.v. leveranciers

Volume materiële overheidsbestedingen

Uren per arbeidsjaar

koers van de dollar gemiddelde jaar-

lijkse \% mutatie $\underline{1986-90}$

$$
4,5
$$

5 à 5,5

$-0,5$

-1 à $-0,5$

1,5

2

1

f1 2,25 
In de middellange-termijn raming wordt een prognose gegeven van het arbeidsvolume (in mensjaren) in 23 bedrijfssectoren in 1990.4 Voor de jaren 1986 en 1987 kunnen deze prognoses worden geactualiseerd op basis van het Centraal Economisch Plan 1987 (CPB 1987-I). Daarnaast is in overleg met het CPB verondersteld dat de ontwikkeling van de sectorale arbeidsvolumes in de jaren 1990-1992 niet zal afwijken van de in de middellange-termijn raming voor 1990 geprognosticeerde groeipaden.

Om de arbeidsvolume-ramingen om te zetten in een prognose van het aantal werkzame personen, heeft een ophoging plaatsgevonden op basis van de in de middellange-termijn raming voor 7 bedrijfssectoren voorspelde verschillen tussen de ontwikkeling van het arbeidsvolume en het aantal werkzame personen. Daar het proces van arbeidsduurverkorting en de groei van de deeltijdarbeid, momenteel enigszins lijken af te nemen, is verondersteld dat de door het CPB geraamde daling van de gemiddelde werktijd per arbeidskracht voor de periode 1985-1990 zich zal spreiden over de periode 1985-1992. In overleg met het CPB zijn daarnaast nog een tweetal kleine correcties aangebracht in de werkgelegenheidsprognoses voor het bank- en verzekeringswezen en de medische en veterinaire diensten. 
Tabel 2 : Prognose werkzame personen naar bedrijfssectoren 1992.

$\begin{array}{ll}\text { Werkzame } & \% \text { mutatie } \\ \text { personen } & 1985-' 92 \\ 1992 & \end{array}$

1. Landbouw, visserij en bosbouw

2. Voedings- en genotmiddelenindustrie

3. Textiel, kleding-, leder-en schoenindustrie

258.900

$-3,5$

168.200

1,5

58.400

71.100

124.000

5

4. Hout- en bouwmaterialenindustrie

5. Papier- en grafische industrie

6. Chemische, rubber- en kunststofverwerkende industrie

7. Basismetaal

8. Metaalprodukten- en optische industrie

132.000

34.100

14

287.500

112.800

80.400

9.500

12.900

45.200

393.100

35.800

839.200

56.600

$-2,5$

8

14

9. Electrotechnische industrie

11. Aardolie-industrie

297.100

191.100

676.500

432.500

480.500

822.200

42.500

13

12

13

0

13

2,5

2

16

16,5

17. Zee- en luchtvaart

18. Overige transport-, opslag- en communicatiebedrijuen

20. Overige tertiaire diensten

21. Medische en veterinaire diensten

22. Overige kwartaire diensten

23. Overheid

24. Sector onbekend

5.662 .100

Tabel 2 geeft een overzicht van deze ramingen. De verwachting is dat de totale werkgelegenheid met $10 \%$ toeneemt ten opzichte van 1985 . Bedrijfssectoren waarvoor een meer dan gemiddelde groei voorspeld wordt zijn de overige tertiaire diensten, handel, woningbezit, medische en veterinaire diensten, chemische industrie, metaalproduktenindustrie, delfstoffenwinning, transportmiddelenindustrie en overige kwartaire diensten. De agrarische sector en de hout- en bouwmaterialen zijn de enige sectoren waarvoor een daling van het aantal werkzame personen wordt verwacht. 
Deze voorspellingen zijn gebaseerd op de geraamde veranderingen van het arbeidsvolume en de verwachte ontwikkelingen in de gemiddelde arbeidstijd per werknemer. De gemiddelde arbeidstijd zal dalen door de verdere arbeidsduurverkorting en de toename van het aantal werkenden in dee1tijdfuncties. Vooral de laatste factor zal in de handel en de kwartaire sector tot een aanzienlijke groei van het aantal werkenden leiden.

\subsection{Beroepsklassen}

De sectorale werkgelegenheidsramingen zijn vervolgens nader gespecificeerd naar 82 beroepsklassen. Daarbij is uitgegaan van twee hypotheses. De eerste hypothese veronderstelt dat een bepalde beroepsklasse sneller in een bedrijfstak kan penetreren, naarmate de werkgelegenheid in een sector sterker groeit. Of, in het omgekeerde geval, dat het aandeel van een bepaalde beroepsklasse in de sectorale werkgelegenheid sneller terugloopt, naarmate de werkgelegenheid in de desbetreffende sector sterker afneemt. Deze hypothese zou kunnen worden aangeduid als de absorptie- of uitstotingssnelheidshypothese.

De tweede hypothese veronderstelt dat het aandeel van een bepaalde beroepsklasse sneller toe- of afneemt, naarmate het produktieproces sterker beinvloed wordt door technologische ontwikkelingen. We spreken in dit verband van de technische ontwikkelingshypothese.

Het toetsen van beide hypothesen is slechts bedoeld als een eerste aanzet voor een theoretisch beter gefundeerde onderbouwing van het optreden van verschuivingen in de sectorale beroepenstructuur. Een dergelijke aanpak biedt belangrijke voordelen ten opzichte van de in eerdere studies (NEI 1986, Ministerie van Sociale Zaken en Werkgelegenheid 1987) gehanteerde methodiek, waarin louter trendmatige ontwikkelingen worden geëxtrapoleerd.

De mogelijkheden tot toetsing van beide hypothesen door middel van tijdreeksonderzoek zijn momenteel nog uiterst beperkt, omdat het aantal werkenden naar beroepsklasse slechts bekend is uit de zes sinds 1975 gehouden Arbeidskrachtentellingen. Het geringe aantal waarnemingsjaren makt het slechts mogelijk beide hypothesen te toetsen door middel van enkelvoudige regressie-analyses. 
Wanneer er voor een beroepsklasse binnen een bedrijfssector geen significant verband wordt geconstateerd tussen de ontwikkeling van het werkgelegenheidsaandeel en een van beide verklarende variabelen, is er ook nog gekeken of er sprake is van een trendmatige ontwikkeling van het werkgelegenheidsaandeel. De gedachte hierachter is dat de trend als een 'proxy' kan fungeren voor de vooralsnog niet adequaat getoetste werking van aanpassingsmechanismen op de arbeidsmarkt.

Daar per sector de som van de prognoses van de werkgelegenheid over de afzonderlijke beroepsklassen gelijk moet zijn aan de als gegeven aangenomen sectorale werkgelegenheidsprognose (zie paragraaf 3.1 .1 ), is er gekozen voor een verdeelmodel (zie ook NEI 1986). Daartoe is voor iedere sector een referentieberoepsklasse gekozen, die in de periode 1975-1985 een redelijk stabiel aandeel in de sectorale werkgelegenheid had en bovendien qua omvang niet te groot of te klein was. Tussen sectoren kunnen de referentieberoepen verschillen, maar per sector is het steeds dezelfde beroepsklasse. Bij de te schatten vergelijkingen is gekozen voor de volgende vorm. 3

$$
\operatorname{Ln}\left(\frac{E_{i j}}{E_{z j}}\right)=\alpha_{i j}+\beta_{i j} x_{j}+u_{i j}
$$

waarbij: $E_{i j}=$ aantal werkzame personen in sector $j$ met beroep $i, E_{z j}=$ aantal werkzame personen in sector $j$ met het referentieberoep $z, x_{j}=$ sectorspecifieke verklarende variabele of een trendvariabele, $\alpha_{i j}, \beta_{i j}$ = regressie coëfficiënten en $u_{i j}=$ storingsterm.

In deze specificatie wordt de ontwikkeling van de werkgelegenheid van beroep $i$ in sector $j$ afgezet tegen de werkgelegenheidsontwikkeling van het referentieberoep in dezelfde sector. De geschatte coëfficiënten geven daarbij aan in hoeverre de desbetreffende beroepsklasse zich verschillend ontwikkeld heeft ten opzichte van het referentieberoep. Met uitzondering van de referentieberoepen zijn er voor iedere beroepsklasse binnen iedere bedrijfssector tien verschillende regressievergelijkingen

3) Om te voorkomen dat het verhoudinggetal $E_{i j} / E_{z j}$ negatieve waarden aanneemt, is van dit verhoudingsgetal de logaritme genomen. 
geschat. Daarbij zijn drie groepen van verklarende variabelen onderscheiden.

De eerste groep betreft de vanuit de absorptie- of uitstotingssnelheidshypothese geformuleerde verklarende variabelen. De verklaringskracht van deze hypothese wordt geanalyseerd op basis van de sectorale werkgelegenheidsontwikkeling, weergegeven door vier indicatoren, die elk afzonderlijk als verklarende variabele kunnen fungeren: het werkgelegenheidsniveau $\left(E_{j}\right)$, de logaritme daarvan $\left(1 n E_{j}\right)$, de absolute verandering van de werkgelegenheid tussen twee waarnemingsjaren $\left(E_{j}\right)$ en de procentuele werkgelegenheidsverandering $\left(E_{j}\right)$. Deze verklarende variabelen zijn alleen opgevoerd voor zover de werkgelegenheid in een sector zich in de periode 1975-1985 in dezelfde richting ontwikkelde, als de voorspelling voor de periode 1985-1992.

Het tweede cluster variabelen staat voor de technische ontwikkelingshypothese. Als proxy-variabelen voor de mate waarin technologische ontwikkelingen de produktieprocessen in een sector vernieuwen, hanteren we de sectorale arbeidsproduktiviteit, de logaritme daarvan of de procentuele verandering van de arbeidsproduktiviteit.

Voor zover verschuivingen in de sectorale beroepenstructuur niet op basis van bovenstaande sectorspecifieke variabelen kunnen worden verklaard, maar deze structuur in de onderzochte periode toch een duidelijk ontwikkelingspatroon laat zien, is onderzocht of de te verklaren variabele toch een bepaalde trendmatige ontwikkeling vertoont. Daarbij zijn regressies uitgevoerd met drie functies van de tijd: $t, \ln (t)$ en $1 / t$.

Op basis van de in bovenstaande regressie-analyse gevonden verbanden zijn de aandelen van de verschillende beroepsklassen in de sectorale werkgelegenheid in 1992 berekend. Daarbij is een viertal uitgangspunten gehanteerd:

1. Regressies zijn alleen uitgevoerd voor zover er in alle waarnemingsjaren minimaal 500 personen in een beroepsklasse binnen een sector werkzaam waren. Dit is gedaan vanwege de relatief zeer brede onbetrouwbaarheidsmarges die bij lage absolute aantallen in acht moeten worden genomen. 
2. Zoals gezegd is steeds wanneer een van de sectorspecifieke verklarende variabelen een significante verklaringskracht heeft, hieraan de voorkeur gegeven boven een trendvariabele.

3. Wanneer sectorspecifieke variabelen significant zijn, is telkens gekozen voor de vergelijking met de hoogste correlatiecoëfficiënt $\left(R^{2}\right)$. Hetzelfde criterium is ook toegepast, wanneer gekozen moest worden tussen meerdere significante trendvariabelen.

4. Als er geen significante verbanden worden gevonden, is verondersteld dat de (log-getransformeerde) verhouding tussen de werkgelegenheid in een beroepsklasse en het aantal werkenden in het referentieberoep in 1992 gelijk is aan het gemiddelde over de periode 1975-1985, tenzij er in de laatste periode toch een duidelijke verschuiving in dit verhoudingsgetal heeft plaatsgevonden. In dat geval wordt de verhouding voor 1992 gelijkgesteld aan de verhouding in 1985.

In een beperkt aantal gevallen, warin er sprake was van een irreële uitschieter in de voorspelling vanuit de op basis van bovenstaande uitgangspunten geselecteerde voorkeursvergelijking, is enigszins van deze beslisregels afgeweken.

Wanneer de prognose voor 1992 plaatsvindt op basis van het gevonden verband met een sectorspecifieke verklarende variabele, is de waarde van $\ln \left(E_{i j} / E_{z j}\right)$ voor 1992 berekend door de prognosewaarde voor de sectorspecifieke variabele in 1992 in de vergelijking in te vullen. Wanneer werd uitgegaan van een significante tijdvariabele is de vastgestelde trend naar het jaar 1992 geëxtrapoleerd. In de overige gevallen is de in de vierde beslisregel geformuleerde procedure gevolgd.

Met behulp van de volgende formule kunnen de prognosewaarden van $E_{i j} / E_{z j}$ worden omgezet in prognoses van de werkgelegnheid in de verschillende beroepsklassen binnen een bedrijfssector:

(2) $\quad \hat{E}_{i j}=\frac{\left(\hat{E}_{i j} / \hat{E}_{z j}\right)}{1+\sum_{i \neq z}\left(\hat{E}_{i j} / \hat{E}_{z j}\right)} \hat{E}_{j}$ 
Een sommatie over de verschillende sectoren geeft vervolgens de voorspelde totale werkgelegenheid in een beroepsklasse in 1992:

(3) $\hat{E}_{i}=\sum_{j=1}^{23} \hat{E}_{i j}$

Tabel 3 laat zien voor welke tien beroepsklassen in de periode 1985-1992 de hoogste absolute of relatieve groei wordt verwacht. De grootste absolute werkgelegenheidstoename zal zich voordoen in twee relatief laaggeschoolde beroepsklassen 'huisbewaarders en schoonmaakpersoneel' en 'winkelbedienden'. Daarna volgen alleen maar relatief geschoolde beroepsklassen.

Relatief gezien is de beroepsklasse 'wiskundigen, systeemanalisten e.d.' veruit het sterkste groeiberoep. De hoge relatieve groei van de beroepsklasse 'bedrijfsleiders land-en tuinbouw' duidt niet op een goed werkgelegenheidsperspectief. Deze groei is louter het gevolg van een verschuiving in de beroepenstructuur van zelfstandige land- en tuinbouwers naar bedrijfsleiders in de agrarische sector.

Tabel 4 vermeldt beroepsklassen waarvoor een dalende of stagnerende werkgelegenheidsontwikkeling wordt verwacht. Onder deze beroepsklassen bevindt zich geen enkele beroepsklasse warin een significant aantal academici werkzaam is. 
Tabel 3: Sterkst groeiende beroepen (absoluut en relatief gezien) 1985-1992

\section{absolute mutatie werkgelegenheid}

1. Huisbewaarders en schoonmaakpersonee 1

2. Winkelbedienden

53.000

42.000

3. Genees- en verpleegkundigen*

38.000

4. Bankemployes, lokettisten, e.d.* 35.000

5. Diverse administratieve functies* 33.000

6. Leerkrachten 31.000

7. Wiskundigen, systeemanalisten, e.d. * 29.000

8. Instrumentmakers, monteurs, e.d.

9. Ingenieurs, tekenaars en verwante technici 22.000

10. Secretaressen en typisten * $\quad 20.000$
1. Wiskundigen, systeemanalisten, e.d.*

2. Bedrijfleiders land-en tuinbouw

3. Huisbewaarders en schoonmaakpersonen

4. Directeuren en bedrijfsleiders horeca-bedrijven 33

5. Juristen* 29

6. Economen* 26

7. Accountants* 25

8. Uitvoerende hoofdambtenaren*

9. Post-distibutiepersoneel

10. Zelfstandige groothandelaren tussenpersonen

* beroepsklasse waarin minimaal 1000 academici werkzaam zijn

Tabe1 4: Beroepsklasse met een dalende of stagnerende werkgelegenheid 1985 - 1992

absolute mutatie
werkgelegenheid

1. Zelfstandige land- en tuinbouwers

2. Agrarische arbeiders

3. Kleermakers, stoffeerders, e.d.

4. Zelfstandige winkeliers

5. Spinners, wevers, ververs, e.d.

6. Vissers e.d.

7. Machinisten, e.d.

8. Goud- en zilversmeden, diamantbewerkers, e.d

9. Bedienaars van de Eredienst

10. Tabaksproduktmakers
25

25

25

relatieve mutatie

\%

57

42

38 9

5
5

25




\subsection{Academische studierichtingen}

De prognoses van de werkgelegenheid naar beroepsklasse zijn vervolgens als uitgangspunt genomen voor de werkgelegenheidsprognoses voor de twaalf studierichtingen waarin het Wetenschappelijk Onderwijs kan worden opgedeeld (zie tabel 5). Naar analogie van de vorige stap, waarin de beroepenstructuur van de verschillende sectoren werd bepaald, is nu een schatting gemaakt van de opleidingsstructuur van de verschillende beroepsklassen in 1992 .

Het data-materiaal waarop een dergelijke prognose kan worden gebaseerd, beperkt zich tot de vier Arbeidskrachtentellingen van 1979 -1985, aangezien het CBS in de Arbeidskrachtentellingen van 1975 en 1977 een niet vergelijkbare onderwijsindeling hanteerde. Daar alleen gekeken werd naar de werkgelegenheidsontwikkeling voor afgestudeerden in het Wetenschappelijk Onderwijs, was het niet noodzakelijk uit te gaan van een verdeelmodel, maar kon direct gekeken worden naar de ontwikkeling van het aandeel van een studierichting in de werkgelegenheid binnen een beroepsklasse.

Ook voor deze stap in het prognosemodel is getracht een verklaringsgrond te vinden voor verschuivingen in het aandeel van een bepaalde opleiding in de werkgelegenheid in een beroepsklasse. In principe kan daarbij een tweetal processen worden onderscheiden. In de eerste plaats kunnen de hoger geschoolden de lager opgeleiden in dezelfde opleidingsrichting verdringen uit een beroep. We kunnen in dit verband spreken van neerwaartse verdringing (De Grip 1987). In de tweede plaats kan er sprake zijn van een proces van horizontale substitutie waarin de groei van het aandeel van een bepalde opleiding ten koste gaat van het aandeel van een andere studierichting van hetzelfde opleidingsniveau. Voor het maken van een werkgelegenheidsprognose is het niet noodzakelijk beide processen afzonderlijk te analyseren. 
Net als in de vorige paragraaf veronderstellen we hier dat er een grotere verschuiving plaatsvindt naarmate de totale werkgelegenheid in een beroepsklasse sterker toeneemt. Ook hier kunnen we weer spreken van een absorptie- of uitstotingssnelheidshypothese. In deze hypothese wordt overigens alleen gekeken naar het 'pull-effect' van het neerwaartse verdringings- c.q. substitutieproces. Het geringe aantal waarnemingsjaren maakt het vooralsnog niet mogelijk naast dit 'pull-effect', ook het 'push-effect' van verschuivingen in de opleidingsstructuur van het arbeidsaanbod in de analyse te betrekken.

De schatting van het opleidingsaandeel in de werkgelegenheid in een beroepsklasse vindt plaats op basis van de volgende regressievergelijking:

$$
\text { (4) } E_{k i} / E_{j}=\theta_{k i}+\psi_{k j} x_{j}+u_{k i}
$$

waarbij: $E_{k j} / E_{j}=$ aantal werkzame personen met opleiding $k$ in beroep $i$ ten opzichte van het totaal aantal werkenden in beroep $i, \theta_{k j}, \psi_{k} i$ = regressie coëfficiënten en $u_{k j}=$ storingsterm.

Voor elke universitaire studierichting binnen iedere beroepsklasse zijn vijf vergelijkingen geschat over de vier waarnemingsjaren tussen 1979 en 1985. De in de eerste twee vergelijkingen getoetste verklarende variabelen zijn de vanuit de absorptie- of uitstotingssnelheidshypothese (neerwaartse verdringing en/of substitutie) geformuleerde variabelen: het werkgelegenheidsniveau in de beroepsklasse $\left(E_{j}\right)$ of de logaritme daarvan $\left(\ln E_{j}\right)$.

Wanneer deze beroepsspecifieke variabelen geen significante verklaringskracht blijken te hebben voor de ontwikkeling van het opleidingsaandeel in de werkgelegenheid, is er gekeken of er sprake is van een trendmatige ontwikkeling van dit opleidingsaandeel op basis van een drietal trendvariabelen: $t$, in $t$ en $1 / t$.

Er zijn ook nu in pincipe geen regressies uitgevoerd wanneer er in een bepaalde beroepsklasse in een bepaald waarnemingsjaar minder dan 500 personen werkzaam waren met de desbetreffende studierichting. Op deze regel moest een aantal uitzonderingen worden gemaakt voor opleidingen, die in de loop van de onderzochte periode ver boven de 500 werkzame personen uitstegen. Daarnaast is ook hier telkens gekozen voor de vergelijking met de hoogste correlatie-coëfficiënt. 
personen uitstegen. Daarnaast is ook hier telkens gekozen voor de vergelijking met de hoogste correlatie-coëfficiënt.

De prognose van het aandeel van een opleiding in de werkgelegenheid in een beroepsklasse in 1992 vond plaats door de voorspelde waarde van de beroepsspecifieke verklarende variabelen in 1992 in de vergelijking in te vullen of door de gevonden trend te extrapoleren naar 1992. Wanneer er geen significante verbanden werden gevonden, is verondersteld dat het aandeel van de opleiding in 1992 gelijk is aan het aandeel van de opleiding in de desbetreffende beroepsklasse in 1985. Dit is gedaan, omdat de meeste universitaire studierichtingen (met veel waarnemingen onder de 500) tussen 1979 en 1985 een toename van het werkgelegenheidsaandeel laten zien. Zou men kiezen voor het gemiddelde aandeel in de periode 1979-1985, dan zou het voorspelde aandeel in 1992 ten onrechte lager worden voorspeld dan het aandeel in 1985.

Wanneer de voorspelde werkgelegenheidsaandelen worden vermenigvuldigd met de geraamde werkgelegenheid in de desbetreffende beroepsklasse, vinden we het aantal werkenden met een bepaalde opleidingsrichting in de beroepsklasse. Sommatie over alle beroepsklassen geeft vervolgens de voorspelling van de totale werkgelegenheid voor academisch geschoolden in de verschillende studierichtingen.

Tabel 5 geeft de werkgelegenheidsverwachtingen voor 1992 voor de academische studierichtingen weer. Het algehele beeld laat zien dat de academisch geschoolden de minder opgeleiden verder uit de werkgelegenheid zullen verdringen. Immers, terwijl het totale aantal werkzame personen in de periode 1985 -'92 volgens onze voorspelling slechts met circa $10 \%$ stijgt (zie tabel 2 ), wordt voor het aantal werkzame academici een toename verwacht van maar liefst $27 \%$.

De relatief hoogste groei wordt daarbij verwacht voor de opleidingsrichtingen econometrie, actuariaat en bedrijfskunde (ir.) en technische wetenschappen. Daarentegen wordt een geringe werkgelegenheidsgroei verwacht voor de medische opleidingen, farmacologie, kunstonderwijs, letteren en theologie. 
Tabe1 5: Prognose werkzame personen naar studierichting in het weten schappelijk onderwijs 1992

\begin{tabular}{cr} 
werkzame personen & $\begin{array}{r}\% \text { mutatie } \\
1992\end{array}$ \\
\hline
\end{tabular}

1. Econometrie, actuariaat en bedrijfskunde (ir.)

2. Technische wetenschappen

5.500

62

3. Sociaal-culturele wetenschappen

54.400

46

4. Rechten

51.500

32

36.400

31

5. Wis- en natuurkunde

27.600

24

6. Agrarische Wetenschappen

6.700

23

7. Economie en bedrijfskunde (drs.)

25.800

22

8. Medische opleidingen

41.800

16

9. Farmacologie

10. Kunstonderwijs

1.900

15

11. Letteren

1.800

15

12. Theologie

18.600

13

Totaal

280.300

27 



\section{VERVANGINGSVRAAG}

\section{$\underline{3.1 \text { Inleiding }}$}

Om een goed beeld te kunnen vormen van de werkgelegenheidsperspectieven van nieuwkomers op de arbeidsmarkt is een voorspelling van de toekomstige werkgelegenheid of werkgelegenheidsgroei niet toereikend. Deze voorspelling geeft slechts een indicatie van het aantal nieuw gecreëerde of verdwenen arbeidsplaatsen. Veel nieuwkomers op de arbeidsmarkt kunnen echter ook terecht komen in functies die gedurende de voorspelperiode vrij komen door het vertrek van degenen die momenteel deze functies bekleden.

In deze studie is daarom ook geprobeerd een schatting te maken van de verwachte vervangingsvraag op de arbeidsmarkt op basis van een prognose van de uitstroom van arbeidskrachten gedurende de periode 1985-1992. Achtereenvolgens zal worden ingegaan op de verwachte vervangingsvraag per beroepsklasse (paragraaf 3.2), de vraag naar schoolverlaters per beroepsklasse (paragraaf 3.3 ) en de verwachte vervangingsvraag voor de verschillende studierichtingen (paragraaf 3.4 ).

\subsection{Vervangingsvraag per beroepsklasse}

De uitstroom van arbeidskrachten in een beroepsklasse kan geschat worden door een onderverdeling te maken in verschillende leeftijdscohorten. Op basis van het beschikbare datamateriaal is gekeken naar de leeftijdsstructuur van de beroepsbevolking in 1985 en 1992. De prognose van de leeftijdsstructuur is afkomstig van het CPB (Op de Beke 1987). Wanneer verondersteld wordt dat er binnen de onderscheiden leeftijdscohorten sprake is van een gelijkmatige spreiding van de beroepsbevolking over de jaargroepen binnen het cohort, kan voor ieder leeftijdsjaar worden bepaald hoeveel arbeidskrachten per saldo de beroepsbevolking verlaten of binnentreden. Daartoe vergelijken we het aantal arbeidskrachten met leeftijd $c$ in 1985 met het aantal arbeidskrachten dat volgens de prognose in $1992 \mathrm{c}+7$ jaar oud is. Op basis hiervan kan de jaarlijkse netto uitstroom uit de beroepsbevolking voor de verschillende leeftijdscohorten $\left(g_{85}-92 V_{B B}\right)$ worden berekend. 
Het ligt echter voor de hand dat de relatieve uitstroom in de verschillende beroepsklassen nogal uiteenloopt. Voor deze beroepsspecifieke component in de uitstroom wordt gecorrigeerd door middel van het verschil tussen het jaarlijkse verloop in een leeftijdscohort in een beroepsklasse en het jaarlijkse verloop in de correspondeerende leeftijdsgroep in de totale werkzame bevolking in de periode $1979-1985$ :

(5) $g_{85-92} V^{V K_{i c}}=g_{85-92}{ }^{V B B}{ }_{c}-\left(g_{79-85} V W P_{c}-g_{79-85} V{ }_{i c}\right)$ waarbij: $g V_{B B K}{ }_{i c}=j_{\text {uit beroepsklasse } i,}$, $\mathrm{g} \mathrm{VBB}_{\mathrm{C}}=\begin{aligned} & \text { idem uit de beroepsbevolking en } \mathrm{g} \mathrm{VWP}_{\mathrm{C}}=\text { idem uit de } \\ & \text { werkzame bevolking. }\end{aligned}$

Verondersteld wordt dat de beroepsklassecomponent in het verloop op jaarbasis tussen 1985 en 1992 dezelfde is als in de periode 1979-'85. Door bij deze correctiefactor een vergelijking te maken met het verloop onder werkzame personen in plaats van met de uitstroom uit de beroepsbevolking, wordt voorkomen dat een conjunctuurcomponent in het verloop (de uitstroom naar de werkloosheid) het beeld verstoort ${ }^{4}$.

Daar het ons hier gaat om het berekenen van de vervangingsvraag en derhalve alleen om de uitstroom, kijken we uitsluitend naar de cohorten waarin de netto-uitstroom positief is (met name de oudere leeftijdsgroepen). Sommatie over deze leeftijdscohorten geeft de berekende totale vervangingsvraag in de desbetreffende beroepsklasse.

Tabel 6 vermeldt de tien beroepsklassen met verhoudingsgewijs de hoogste en de tien beroepsklassen met de relatief laagste verwachte vervangingsvraag gedurende de periode 1985 - 1992. De gemiddelde vervangingsvraag in deze periode bedraagt ca. $18 \%$ van het aantal werkenden in 1985. Een vergelijking van dit percentage met de verwachte werkgelegenheidsgroei van $10 \%$, laat zien hoe belangrijk het incorpereren van de vervangingsvraag in de werkgelegenheidsprognoses is.

${ }^{4}$ ) Dit geldt alleen voor zover de relatieve uitstroom van een beroepsklasse naar de werkloosheid niet afwijkt van het gemiddelde. 
Voor verschillende met name industriële beroepsklassen is de gevonden vervangingsvraag duidelijk hoger dan gemiddeld. Daarbij moet wel bedacht worden dat het hier in veel gevallen gaat om beroepsklassen waarin de werkgelegenheidsontwikkeling stagneert, waardoor de feitelijke vervanging slechts plaatsvindt voor zover de werkgelegenheid in de desbetreffende beroepsklasse niet afneemt.

Bij de beroepsklassen met een relatief lage vervangingsbehoefte treffen we diverse beroepen aan met een relatief jonge populatie, waaronder verschillende beroepen met veel academisch geschoolde arbeidskrachten. Voor verschillende van deze beroepsklassen wordt een relatief gunstige werkgelegenheidsontwikkeling verwacht. Een uitzondering hierop vormt de beroepsklasse tabaksproduktenmakers. 
Tabel 6: Beroepsklasse met relatief de hoogste en de laagste vervangingsvraag 1985 - 1992

absolute ver- in \% van werkza-

vanginsvraag me personen 1985

Hoge vervangingsvraag

1. Spinners, wevers,

$$
\text { ververs, e.d. }
$$

2. Overige arbeiders

(sjouwers e.d.

3. Mijn-, groeve-arbeiders, bronboorders e.d.

4. Meubelmakers e.a. houtbewerkers

5.300

46

18.200

40

700

37

6.100

37

4.600

35

2.500

34

57.500

34

34.700

33

4.300

33

13.100

32

\section{$\underline{\text { Lage vervangingsvraag }}^{* *}$}

1. Radio- en T.V.-zend, geluids-, beeldapparatuurbedieners

2. Statistici, wiskundigen, systeemanalisten en verwante vakspecialisten

3. Auteurs, journalisten e.d.*

4. Tabaksproduktenmakers

6. Directeuren en bedrijfsleiders groothandel

$\begin{array}{ll}2.300 & 8\end{array}$

7. Musici, toneelspelers e.a. uitvoerende kunstenaar

8. Sociale hulpverleners, vertalers e.d.

9. Biologen, biochemici, landbouwkundigen en verwante specialisten

10. Directeuren en bedrijfsleiders detailhandel

** beroepsklasse waarin minimaal 1000 academici werkzaam zijn. een erg kleine beroepsklasse is hier buiten beschouwing gelaten. 


\subsection{Vraag naar 'schoolverlaters' per beroepsklasse}

Sommatie van de uitbreidingsvraag (werkgelegenheidsmutatie) en de vervangingsvraag geeft de totale vraag naar nieuwkomers in een beroepsklasse gedurende de prognose periode 1985-1992. Voor een deel zullen deze vrijkomende arbeidsplaatsen worden opgevuld door arbeidskrachten, die voorheen werkzaam waren in andere beroepsklassen (beroepsmobiliteit) en door herintreders in de beroepsbevolking. Gegeven deze beroepsmobiliteit en herintreding, kan de totale vraag naar schoolverlaters in een beroepsklasse als volgt worden gedefinieerd:

(6) $V S_{j} \equiv \Delta E_{i}+\left(U_{i}-H_{j}\right)$

waarbij: VS = vraag naar schoolverlaters, $\Delta E=$ mutatie werkgelegenheid, $U=$ uitstroom, $H=$ herintrede, $i=$ beroepsklasse

Voor de berekening van de netto uitstroom (U-H) is dezelfde methodiek gehanteerd als bij het berekenen van de vervangingsvraag in een beroepsklasse. Er is nu echter niet alleen gekeken naar de leeftijdscohorten waarvoor de voorspelde netto-uitstroom positief is, maar ook naar de cohorten waar er sprake is van een nettoherintrede. Daarbij wordt verondersteld dat er in de leeftijdsgroepen < 30 jaar alleen 'schoolverlaters' in een beroepsklasse instromen. In de praktijk zal dit natuurlijk lang niet altijd het geval zijn. Vandaar dat, wanneer hiervan 'schoolverlaters' wordt gesproken, het in feite gaat om de instroommogelijkheden van arbeidskrachten jonger dan 30 jaar in een beroepsklasse.

Tabel 7 vermeldt de beroepsklassen waarvoor tussen 1985 en 1992 in absolute of in relatieve zin de grootste vraag naar schoolverlaters wordt verwacht. Absoluut gezien zullen er veel 'schoolverlaters' kunnen instromen als winkelpersoneel, administratieve kracht, bouwvakker of (genees- of) verpleegkundige. Relatief gezien is de vraag naar nieuwe jonge arbeidskrachten het hoogst in de beroepsklasse directeuren en bedrijfsleiders horecabedrijven. Daarna volgen diverse industriële beroepen. Ook de vraag naar uitvoerende hoofdambtenaren is opvallend hoog. 
Tabel 7: Beroepsklassen met absoluut of relatief gezien de grootste vraag naar 'schoolverlaters' $1985-1992$

Absoluut hoge vraag

vraag naar schoolverlaters

$1985-1992$
Relatief hoge vraag**

vraag naar schoolverlaters in \% werkenden in 1985
1. Winkelbedienden

86.900

2. Diverse administratieve functies

78.200

3. Bankemployes, lokettisten

70.310

4. Metselaars, timmerlieden e.a. bouwvakarbeiders 60.100

5. Instrumentmakers, monteurs, e.d.

54.900

6. Secretaressen en typisten

44.100

7. Chauffeurs, matrozen e.d.

43.200

8. Laders, lossers, inpakkers, e.d.

40.300

9. Genees- en verpleegkundigen*

40.300

10. Loodgieters, pijpfitters, lassers, plaat- en constructiewerkers 39.700
1. Directeuren en bedrijfsleiders horecabedrijven 62

2. Houtzagers, papiermakers e.d.

3. Meubelmakers e.a. houtbewerkerswerkers $\quad 48$

4. Uitvoerende hoofdambtenaren*

5. Spinners, wevers, ververs, e.d.

6. Loodgieters, pijpfitters, lassers, plaaten constructiewerkers

7. Diverse ambachts- en industrieberoepen*

8. Smeden, gereedschapmakers, machinale metaalbewerkers

9. Metselaars, timmerlieden e.a. bouwvakarbeiders

10. Schilders e.d.

\footnotetext{
** Beroepsklassen waarin minimaal 1000 academici werkzaam zijn Beroepsklassen met een mutatie $<1000$ zijn hier buiten beschouwing gelaten.
}

In de beroepsklassen waarin men vaak pas op latere leeftijd instroomt, zoals bv. de beroepsklasse 'beleidsvoerende en hogere leidinggevende functies (exclusief openbaar bestuur)', is de netto-uitstroom veelal negatief, wat kan betekenen dat de vraag naar schoolverlaters in deze beroepsklasse ondanks een toename van de werkgelegenheid, nihil kan zijn.

Tabel 8 vermeldt de 23 beroepsklassen warvoor in de periode 1985-1992 geen directe instroom van schoolverlaters wordt verwacht. Uit deze lijst blijkt dat diverse leidinggevende beroepen niet direct voor schoolverlaters open staan. Daarnaast zien we nog een aantal beroepsklassen waarin de geringe werkgelegenheidsgroei volledig wordt opgesoupeerd door de instroom uit andere beroepsklassen. 
Tabel 8: Beroepsklassen waarvoor in de periode 1985-1992 geen directe instroom van schoolverlaters wordt verwacht

- Leerlooiers, pelsbewerkers e.d.

- Radio-, TV- en geluids- beeldapparatuurbedjeners

- Directeuren en bedrijfsleiders groothandel

- Beleidvoexrende en hogere leidinggevende functies bij openbaar bestuur)

- Beleidvoerende en ${ }_{*}$ hogere leidinggevende functies (exclusief openbaar bestuur)

- Auteurs, journalisten, e.d.*

- Bedienaars van de eredienst, e.d.*

- Toezichthoudend- en leidinggevend huishoudelijk personeel

- Toezichthoudend- en leidinggevend administratief personeel

- Bedrijfsleiders land- en tuinbouw

- Steenhouwers, -zagers, -slijpers, e.d.

- Verzekeringsagenten, makelaars, e.d.

- Diverse ambachts- en industrieberoepen

- Musici, toneelspelers e.a. uitvoerende kunstenaars

- Vissers, ${ }^{e} \cdot d_{\text {. }}$

- Juristen

- Toezichthoudend- en leidinggevend transport- en communicatie personeel

- Post-distributiepersoneel

- Directeuren en bedrijfsleiders detailhandel

- Toezichthoudend- en leidinggevend produktiepersoneel

- Rubber - en plasticproduktenmakers

- Tabaksproduktenmakers

- Sociale hulpverleners, vertalers, e.d.*

* = beroepsklasse waar minimaal 1000 academici werkzaam zijn.

\subsection{Vervangingsvraag naar academische studierichting}

Bij het traceren van de vervangingsvraag per studierichting kan de in de paragraaf 3.2 beschreven methodiek niet worden gehanteerd, omdat de beroepsmobiliteit van arbeidskrachten dan het beeld zou vertekenen. Immers, de uitstroom uit een bepaalde beroepsklasse zal voor een deel weer instromen in andere beroepsklassen, waarin arbeidskrachten later in hun loopbaan terecht komen. Daarom moet worden volstaan met het geven van een grove benadering van de te verwachten uitstroom. Daarvoor is gekeken naar het aantal arbeidskrachten in een beroepsgroep dat in 198555 jaar of ouder is. Verondersteld wordt dat deze groep tussen 1985 en 1992 in zijn geheel uitstroomt. Waarschijnlijk betekent dit dat het verloop in deze leeftijdscohorten enigszins wordt overschat. Daar staat tegenover dat de uitstroom uit de werkende bevolking van degenen die in 1985 nog geen 55 jaar oud waren buiten beschouwing blijft. Echter ook met de herintreding van academisch geschoolden en met de werkenden die op latere 
leeftijd een academische studie afronden wordt hier geen rekening gehouden.

Vervolgens is de aldus berekende uitstroom uit een

beroepsklasse omgerekend naar de verschillende studierichtingen door het verloop te vermenigvuldigen met het aandeel van de afgestudeerden in de desbetreffende beroepsklasse in $1985^{5}$. Sommatie over de verschillende beroepsklassen geeft dan het berekende totale verloop en daarmee de geraamde vervangingsvraag per studierichting $\left(V_{S R_{k}}\right)$ :

(7) $\operatorname{VSR}_{k}=\sum_{i=1}^{m}\left(a_{k i} V_{B K_{i}}\right)$

In tabel 9 is voor de twaalf onderzochte studierichtingen de verwachte vervangingsvraag tussen 1985 en 1992 uitgedrukt in de vorm van een percentage van het aantal werkenden in 1985. Veruit de hoogste vervangingsvraag wordt verwacht voor theologie. Ook is er een relatief hoge vervangingsbehoefte bij economie en bedrijfskunde (drs) en rechten. De laagste vervangingsvraag wordt daarentegen verwacht voor de medische opleidingen en farmacologie.

Tabe1 9: Vervangingsvraag naar studierichting in het Wetenschappelijk onderwijs (in \% van het aantal werkenden in 1985)

1. Theologie

2 Economie en bedrijfskunde (drs) 13

3. Rechten

4 Technische wetenschappen

Econometrie, Actuariaat en bedrijfskunde

10

6. Agrarische wetenschappen en huishoudkunde Sociaal-culturele wetenschappen

8. Wis- en natuurkunde

Letteren

Kunstonderwijs

11. Medische opleidingen

Farmacologie

Gemiddeld

9

5 Deze aanpak veronderstelt - waarschijnlijk in aantal gevallen ten onrechte - dat het aandeel van een studierichting in de oudere leeftijdsgroepen gelijk is aan het aandeel van de studierichting in het totale aantal werkenden in de beroepsklasse. Ook hierdoor kan een vertekening van het beeld, doorgaans in de vorm van een overschatting van het verloop van hoger opgeleiden, opgetreden. 


\section{DE ARBEIDSMARKTSITUATIE NAAR ACADEMISCHE STUDIERICHTING}

In dit hoofdstuk zal voor de twaalf onderzochte academische studierichtingen een typering worden gegeven van de arbeidsmarktsituatie in 1992. Deze typering is gebaseerd op de verwachte totale vraag naar nieuwkomers op de arbeidsmarkt met de desbetreffende opleiding en de geraamde instroom van afstuderenden gedurende de periode 1985 - 1992.

Sommatie van de verwachte werkgelegenheidsmutatie (de uitbreidingsvraag) en de vervangingsvraag geeft de totale behoefte aan nieuwkomers op de arbeidsmarkt met een bepaalde opleiding (VN). Deze totale vraag naar nieuwe arbeidskrachten mag niet verward worden met de totale vraag naar arbeid op een bepaald moment. Met dit laatste statische begrip wordt doorgaans gedoeld op de totale werkgelegenheid op een bepaald moment. In tabel 9 is de totale behoefte aan nieuwkomers voor de verschillende studierichtingen telkens uitgedrukt in procenten van het totaal aantal werkenden in 1985.

Om te kunnen komen tot een typering van de verwachte arbeidsmarktsituatie in 1992 voor de verschillende studierichtingen, is het noodzakelijk de vraagvoorspellingen te confronteren met een voorspelling van de verwachte instroom van afstuderenden in de periode 1985-1992. Op basis van globale CPB-prognoses publiceert de Taakgroep Studentenramingen ieder jaar een meer gedetailleerde raming van de toekomstige jaarlijkse aantallen afstuderenden in het Wetenschappelijk Onderwijs, de zgn. WORSAprognoses (Taakgroep Studentenramingen 1986-I).

Deze prognoses zijn het uitgangspunt geweest voor onze raming van het aantal afstuderenden in de verschillende studierichtingen. Daarbij is gekeken naar de WORSA-prognoses voor de studiejaren 1985 - '86 tot 1991 - '92, voor zowel de oude-stijl studies als de eerste-fase nieuwe stijl opleidingen in het Wetenschappelijk Onderwijs. De WORSA-data zijn door ons op een tweetal punten bewerkt. In de eerste plaats zijn de ramingen van de verschillende studies opgedeeld over de twalf door ons onderscheiden studierichtingen. In de tweede plaats is om de cijfers vergelijkbaar te maken met de vraagprognoses, bij een aantal studierichtingen ook gekeken naar het verwachte aantal afstuderenden aan enkele niet-universitaire opleidingen, die in de Standaard Onderwijs Indeling toch tot het hoogste opleidingsniveau worden gerekend. Het gaat 
hier om een viertal opleidingen: de Bouwkunst Academie (toegevoegd aan de studierichting technische wetenschappen), de Voortgezette Agogische Beroepsopleiding (toegevoegd aan de sociaal-culturele wetenschappen), de NIVRA accoutancy-opleidingen (toegevoegd aan de economische wetenschappen) en de Rijksacademies Beeldende Kunst (toegevoegd aan het kunst-onderwijs) ${ }^{6}$. Om de vergelijkbaarheid met de vraagveranderingen te vergemakkelijken is het aantal afstuderenden telkens uitgedrukt in de vorm van een percentage van het aantal werkzame personen in 1985 (AN).

Met uitzondering van de studierichtingen theologie en technische wetenschappen blijkt het aantal afstuderenden in de voorspelperiode voor de meeste studierichtingen in het Wetenschappelijk Onderwijs in verhouding tot het aantal werkenden erg groot te zijn (zie tabel 10). Naast een trendmatige stijging van het aantal afstuderenden in veel studierichtingen wordt dit veroorzaakt, doordat er in een aantal jaren sprake is van een dubbele instroom op de arbeidsmarkt van oude en nieuwe stijl opgeleiden. Mogelijk heeft de hoge werkloosheid in de eerste helft van de jaren ' 80 tot een grotere doorstroming van middelbare scholieren en HBO-abituriënten naar het Wetenschappelijk Onderwijs geleid.

Door een vergelijking te maken tussen de door ons berekende totale vraag naar nieuwe arbeidskrachten met een bepaalde opleiding in de periode 1985-'92 en de verwachte instroom op de arbeidsmarkt van afstuderenden in hetzelfde tijdvak, is geprobeerd een indicatie te geven van de arbeidsmarktsituatie waarin degenen die in 1992 afstuderen in een bepaalde studierichting zullen terechtkomen. We hanteren hiervoor slechts een globale indicator, omdat het ons inziens niet verantwoord is om op basis van de vraag en aanbod-prognoses een ('punt'-)voorspelling te maken van de verwachte werkloosheid in het prognosejaar. Ten eerste omdat met name de vervangingsvraag-ramingen voor de verschillende studierichtingen slechts indicatief zijn. Ten tweede omdat onze prognoses van de werkgelegenheidsontwikkelingen voor academici waarschijnlijk nog onvoldoende rekening houden met de neerwaartse ver-

6 Data voor de eerste twee opleidingen zijn afkomstig uit de zogenaamde RHOBOS-voorspellingen van het HBO (Taakgroep Studen tenramingen 1986-II). De NIVRA-data zijn daarentegen door ons op basis van extrapolatie van de gevonden trend in het verleden bepaald, terwijl de cijfers van de Rijksacademies beeldende kunst zijn gebaseerd op door deze academies versterkte inlichtingen. 
dringingsprocessen die ongetwijfeld zullen optreden, wanneer de historisch gezien erg hoge aantallen afstuderenden in de periode 19851992 hun plek op de arbeidsmarkt proberen te veroveren (zie ook paragraaf 2.4). Desalniettemin achten wij de door ons berekende indicator, het quotiënt van enerzijds de instroom van afstuderenden en anderzijds de vervangings- en uitbreidingsvraag in de periode 19851992, wel degelijk maatgevend voor een globale typering van de arbeidsmarktsituatie in 1992.

Tabel 10: Typering arbeidsmarktsituatie naar studierichting $(1985$ - 1992)

\begin{tabular}{|c|c|c|c|c|}
\hline & & 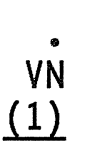 & $\begin{array}{l}\dot{A N} \\
(2)\end{array}$ & $\begin{array}{l}\text { Arbeidsmarkt } \\
\text { indicator } \\
\text { (2):(1) }\end{array}$ \\
\hline $\begin{array}{l}1 . \\
2 . \\
3 . \\
4 . \\
5 . \\
6 . \\
7 . \\
8 . \\
9 . \\
10 . \\
11 . \\
12 .\end{array}$ & $\begin{array}{l}\text { Theologie } \\
\text { Technische Wetenschappen } \\
\text { Econometrie, actuariaat en bedrijfskunde (ir) } \\
\text { Medische opleidingen } \\
\text { Rechten } \\
\text { Sociaal-culturele wetenschappen } \\
\text { Wis- en natuurkunde } \\
\text { Economische wetenschappen en bedrijfskunde (drs) } \\
\text { Agrarische wetenschappen en huishoudkunde } \\
\text { Letteren } \\
\text { Farmacologie } \\
\text { Kunstonderwijs }\end{array}$ & $\begin{array}{l}32 \\
55 \\
72 \\
21 \\
43 \\
40 \\
31 \\
35 \\
31 \\
20 \\
21 \\
23\end{array}$ & $\begin{array}{l}11 \\
47 \\
108 \\
45 \\
96 \\
91 \\
79 \\
97 \\
119 \\
126 \\
137 \\
224\end{array}$ & $\begin{array}{l}0.3 \\
0.9 \\
1.5 \\
2.2 \\
2.2 \\
2.3 \\
2.5 \\
2.7 \\
3.8 \\
6.3 \\
6.7 \\
9.9\end{array}$ \\
\hline & $\begin{array}{l}=\text { vraag naar nieuwkomers in procenten van werkzar } \\
=\text { aantal afstuderenden in procenten van werkzame }\end{array}$ & e & 501 & 1985. \\
\hline
\end{tabular}

Uit de cijfers van tabel 10 blijkt dat alleen voor de studierichtingen theologie en technische wetenschappen de arbeidsmarktindicator kleiner is dan 1. De studierichtingen letteren, farmacologie en het kunstonderwijs vertonen daarentegen een erg hoge verhouding tussen de verwachte instroom van afstuderenden en de vraag naar nieuwkomers. 


\section{ENKELE RISICO INDICATOREN}

\section{$\underline{5.1 \text { Inleiding }}$}

In het eerste hoofdstuk werd reeds opgemerkt dat het afstemmen van de studiekeuzebeslissing op de arbeidsmarkt plaatsvindt in een situatie van onzekerheid. Prognoses van de arbeidsmarktsituatie op het moment van afstuderen kunnen deze onzekerheid voor een deel doen afnemen. Hoewel het vinden van een eerste werkkring in belangrijke mate bepalend is voor de vraag of men met een bepaalde studierichting een grote kans loopt later werkloos te worden, is het ook van belang om te weten hoe de werkloosheidskansen op latere leeftijd in de beroepsloopbaan liggen.

Vanuit deze invalshoek zijn voor de verschillende beroepsklassen indicatoren berekend voor de mate waarin de werkgelegenheid in een beroepsklasse fluctueert (paragraaf 5.2) en voor de uitwijkmogelijkheden naar andere bedrijfssectoren die een beroepsklasse biedt (de branchespreiding) (paragraaf 5.3). Analoog aan de tweede indicator is voor de verschillende studierichtingen een indicator berekend voor de uitwijkmogelijkheden naar andere beroepsklassen, die men met een bepaalde studierichting heeft (de beroepenspreiding) (paragraaf 5.4).

Naast de informatie die deze indicatoren geven met betrekking tot de werkgelegenheidsperspectieven na 1992, geven de indicatoren ook een indruk van de kans dat de voorspellingen voor 1992 minder juist zouden kunnen zijn als gevolg van niet voorziene fluctuaties in de werkgelegenheidsontwikkeling en van de mogelijkheden die er voor individuele arbeidskrachten openstaan uit te wijken naar andere bedrijfssectoren of beroepen.

\subsection{Werkgelegenheidsfluctuaties in beroepsklassen}

De stabiliteit van de werkgelegenheidsontwikkeling in een bepaald beroep kan zowel door een structurele inkrimping als door conjuncturele fluctuaties van de werkgelegenheid in het desbetreffende beroep worden aangetast. 
Om een indruk te krijgen van de mate waarin met name conjuncturele fluctuaties van de werkgelegenheid een rol kunnen spelen, is voor de verschillende beroepsklassen een (werkgelegenheids)fluctuatie-index geconstrueerd. Eerst is in navolging van een studie van het NEI (1972) voor 23 bedrijfssectoren een fluctuatie-index berekend over de periode 1950-1985. Deze berekening is als volgt:

(8) $\quad F I_{j}=\frac{100}{h} \sum_{t=1}^{h} \frac{\left|F_{j t}\right|}{T_{j t}}$

waarbij: $F I_{j}=$ fluctuatie-index bedrijfstak $j, h=$ aantal waarnemingsjaren, $t=$ jaar, $F_{j}=$ afwijking van trendmatige werkgelegenheidsontwikkeling bedrijfstak $j, T_{j}=$ trendmatige werkgelegenheidsontwikkeling bedrijfstak $j$.

Vervolgens zijn voor iedere beroepsklasse de fluctuatie-indices voor alle bedrijfstakken gewogen met het aandeel van de desbetreffende beroepsklasse in de werkgelegenheid van de verschillende bedrijfstakken:

(9) $\quad F I_{j}=\sum_{j=1}^{n} a_{i j} F I_{j}$

waarbij: $F I_{j}=$ flucatuatie-index beroepsklasse $i, a_{i j}=$ aandee 1 beroepsklasse $i$ in werkgelegenheid bedrijfsklasse $j$.

Deze berekeningswijze impliceert de veronderstelling dat de werkgelegenheid van de verschillende beroepen binnen een bedrijfstak in gelijke mate fluctueert (in de praktijk is dit natuurlijk lang niet altijd het geval).

Tabel 11 vermeldt de tien beroepsklassen met de grootste en de tien beroepsklassen met de kleinste werkgelegenheidsfluctuaties. 
Tabel 11: Beroepsklassen met de grootste en de kleinste werkgelegenheidsfluctuaties (1950-1985)

\section{Grootste fluctuaties}

$\mathrm{FI}_{\mathbf{i}}$

1. Mijn-, groeve-arbeiders, bronboorders e.d.

36,6

2. Spinners, wevers, ververs, e.d.

3. Schoenmakers en lederwarenmakers

4. Kleermakers, stoffeerders, e.d.

5. Leerlooiers, pelsbewerkers, e.d.

6. Rubber- en plasticproduktenmakers

7. Metselaars, timmerlieden e.a. bouwvakarbeiders

8. Steenhouwers, -zagers, -slijpers e.d.

9. Hoogovenarbeiders, walsers, gieters, e.d.

10. Chemische procesarbeiders

\section{Kleinste fluctuaties}

1. Conducteurs trein, bus, e. $d_{*}$

2. Uitvoerende hoofdambtenaren

3. Leerkrachten

4. Beleidvoerende en hogere leidjinggevende

functies bij openbaar bestuur

5. Post-distributiepersonee 1

6. Brandweer-, politiepersoneel, bewakers, e.d.

7. Zelfstandige hotel- en caféhouders, e.d.

8. Juristen

9. Accountants*

10. Kappers, schoonheidsspecialisten, e.d.

* beroepsklasse waarin minimaal 1000 academici werkzaam zijn
34,4

27,7

26,6

25,3

25,1

24,1

23,9

23,1

22,0

2,7

4,2

4,3

4,5

4,5

5,8

6,0

6,2

6,3

6,3

\subsection{Branchespreiding van beroepsklassen}

Wanneer een bepaald beroep sterk geconcentreerd is in een beperkt aantal bedrijfstakken, zal de werkgelegenheidsontwikkeling van dit beroep in belangrijke mate afhankelijk zijn van het wel en wee van deze bedrijfstakken. Een duidelijk voorbeeld hiervan is de beroepsklasse leerkrachten waarvan $96 \%$ werkzaam is in de overheids(onderwijs)sector. Wanneer de werkgelegenheidsontwikkeling in deze sector stagneert heeft men weinig uitwijkmogelijkheden naar andere bedrijfssectoren.

Warnken (1986) heeft een maatstaf geconstrueerd die aangeeft in welke mate een beroepsklasse geconcentreerd is in een beperkt aantal bedrijfssectoren. We spreken in dit verband van de indicator van de "branchespreiding" van een beroepsklasse. Deze zgn. Gini-Hirschman coëfficiënt wordt als volgt berekend: 
(10) $\mathrm{GH}_{j}=\left(1-\sum_{j=1}^{n} b_{i j}{ }^{2}\right) \frac{n}{n-1}$

waarbij: $\mathrm{GH}_{\mathbf{j}}=$ Gini-Hirschman coëfficiënt, beroepsklasse $i, b_{i j}=$ aandee 1 beroepsklasse $i$ in bedrijfstak $j, n=$ aantal bedrijfstakken.

In deze spreidingsindicator corrigeert de term $(n / n-1)$ voor het aantal bedrijfstakken waar naar wordt gekeken. Hier is voor alle beroepsklassen de spreiding over 54 beroepsklassen geanaliseerd.

De waarde van deze indicator kan uiteenlopen van 0 tot 1 . Bij een waarde van 0 is het beroep geheel geconcentreerd in 1 bedrijfstak. Een waarde van 1 duidt daarentegen op een volledig gelijke spreiding over de verschillende bedrijfstakken.

Tabel 12 laat de beroepsklassen zien met de grootste en met de kleinste branchespreiding over de periode 1979 - 1985. Met name bij leidinggevende en administratieve beroepen is de branchespreiding groot. Beroepsklassen met een geringe branchespreiding hebben in veel gevallen ook reeds een sectorspecifieke naam. 
Tabel 12: Beroepsklassen met de grootste en de kleinste branchespreiding (gemiddelde 1979 - 1985)

Grote branchespreiding

$\underline{\mathrm{GH}}_{\mathbf{i}}$

1. Beleidvoerende en hogere leidinggevende functies

(exclusief openbaar bestuur)

2. Secretaressen, typisten, e.d.*

0.99

0.94

3. Diverse administratieve functies ${ }^{*}$

0.94

4. Toezichthoudend- en leidinggevend produktiepersonee 1

0.94

5. Laders, lossers, inpakkers, e.d.

0.94

6. Telefonisten, e.d.

0.94

7. Toezichthoudend- en leidinggevend transporten communicatiepersonee 1

8. Computerapparatuur-operateurs e.d.

0.93

9. Instrumentmakers, monteurs, ${ }_{*}$.d.

0.93

10. Ingenieurs, tekenaars, e.d.

0.92

\section{Geringe branchespreiding}

1. Zelfstandige land- en tuinbouwers $\quad 0.00$

2. Zelfstandige winkeliers 0.01

3. Zelfstandige hotel-, restaurant-, cafehouders, e.d. 0.02

4. Directeuren en bedrijfsleiders groothande ${ }^{*} \quad 0.02$

5. Tabaksproduktenmakers 0.02

6. Zelfstandige groothandelaren en tussenpersonen 0.03

7. Steenhouwers, -zagers, -slijpers, e.d. 0.03

8. Directeuren en bedrijfsleiders detailhandel 0.04

9. Kappers, schoonheidsspecialisten, e.d. 0.07

10. Beleidvoerende en hogere leidinggevende functies

bij openbaar bestuur

0.09

* beroepsklassen waarin minimaal 1000 academici werkzaam zijn

\subsection{Beroepenspreiding van academische studierichtingen}

Op soorgelijke wijze als bij de branchespreiding van een beroepsklasse, is ook de beroepenspreiding van de verschillende studierichtingen te bepalen. Daabij zijn 83 beroepsklassen onderscheiden.

(11) $\mathrm{GH}_{k}=\left(1-\sum_{i=1}^{\mathrm{m}} \mathrm{e}_{\mathrm{k} i}{ }^{2}\right) \frac{\mathrm{m}}{\mathrm{m}-1}$

waarbij: $\mathrm{GH}_{k}=$ Gini-Hirschmancoëfficiënt studierichting $k, e_{k j}=$ aandeel studierichting $k$ in beroepsklasse $i, m=$ aantal beroepsklassen.

Bij een waarde van 0 leidt een studierichting slechts op voor een bepaalde beroepsklasse. Een waarde van 1 duidt daarentegen op een volledige gelijkmatige beroepenspreiding. 
Deze beroepenspreidingsindicator geeft aan wat de arbeidsmarktflexibiliteit is van een bepaalde studierichting, met andere woorden: hoeveel kanten een leerling op kan als hij of zij de desbetreffende studie met succes heeft afgerond. Tabel 13 geeft een beeld van de uitwijkmogelijkheden van de verschillende studierichtingen. Voor de meeste opleidingsrichtingen blijkt de beroepenspreiding vrij groot te zijn. Alleen bij de medische opleidingen is er sprake van een vrij directe koppeling aan een bepaalde beroepsklasse. Daarbij moet wel bedacht worden dat het hier gaat om globale studierichtingen, hetgeen in bepaalde gevallen kan leiden tot een overschatting van het flexibiliteitspotentieel van een meer specifieke studierichting.

Tabel 13: Beroepenspreiding van de studierichtingen in het Wetenschap pelijk Onderwijs (gemiddelde 1979 -1985)

$\underline{\mathrm{CH}}_{\mathrm{K}}$

1. Economische Wetenschappen en bedrijfskunde (drs) 0.86

2. Agrarische Wetenschappen en huishoudkunde 0.82

3. Wis- en natuurkunde $\quad 0.81$

4. Econometrie, actuariaat en bedrijfskunde (ir) 0.80

5. Kunstonderwijs $\quad 0.79$

$\begin{array}{ll}\text { 6. Rechten } & 0.70\end{array}$

7. Technische wetenschappen 0.68

8. Sociaal-culturele wetenschappen 0.66

9. Letteren 0.53

10. Farmacologie 0.51

11. Theologie 0.49

12. Medische opleidingen $\quad 0.22$ 



\section{ARBEIDSMARKTPERSPECTIEVEN}

\section{$\underline{6.1}$ Inleiding}

In de hoofdstukken 3 en 4 van deze studie zijn de werkgelegenheids- en vervangingsvraagvoorspellingen telkens uitgedrukt in procenten van het aantal werkenden in 1985. Gezien de onzekerheid waaraan dergelijke prognoses onderhevig zijn, is het ons inziens niet zinvol bij de studie-en beroepskeuze beslissingen veel nadruk op dergelijke 'punt'-schattingen te leggen. Beter is het, om op basis van de prognoses kwalitatieve uitspraken te doen met betrekking tot de werkgelegenheidsperspectieven in de verschillende beroepsklassen en studierichtingen, waarbij de meer exacte prognose-uitkomsten voor degenen die hiervoor belangstelling hebben als achtergrondinformatie zouden kunnen fungeren. Ook de in het voorgaande hoofdstuk besproken risico-indicatoren zullen worden omgezet in een kwalitatieve typering. Paragraaf 6.1 gaat in op de wijze waarop de verschillende beroepsklassen zijn getypeerd. In paragraaf 6.2 wordt een typering gegeven van de twaalf academische studierichtingen

\subsection{Perspectieven van beroepsklassen}

Voor de beroepsklassen beschikken we door het ontbreken van arbeidsaanbodprognoses naar beroep, slechts over prognoses van de totale vraag naar nieuwkomers op de arbeidsmarkt en van de vraag naar schoolverlaters gedurende de periode 1985 - 1992. Bij de typering van de werkgelegenheidsperspectieven in de verschillende beroepsklassen baseren we ons op de eerstgenoemde maatstaf. Daarnaast zal telkens worden aangegeven wanneer een beroepsklasse niet direct open staat voor schoolverlaters (zie tabe 1 8). Tevens maken we gebruik van de indicatoren voor de werkgelegenheidsfluctuaties en de branchespreiding. Bij de typering van de beroepsklassen hanteren we de volgende classificaties:

Vraag naar nieuwkomers (VN)

VN $\geq 32 \%$ goed werkgelegenheidsperspectief

$24 \leq \mathrm{VN}<32 \%$ redelijk werkgelegenheidsperspectief

$18 \leq \mathrm{VN}<24 \%$ matig werkgelegenheidsperspectief

VN $<18 \%$ slecht werkgelegenheidsperspectief 
Werkgelegenheidsfluctuaties (FI)

$\mathrm{FI} \geq 15 \%$ erg conjunctuurgevoelig

$\mathrm{FI}<15 \%$ weinig conjunctuurgevoelig

Branchespreiding (GH)

$0,3<\mathrm{GH} \leq 1,0$ uitwijkmogelijkheden

$\mathrm{GH} \leq 0,3$ weinig uitwijkmogelijkheden

Schema I laat zien hoe de 82 beroepsklassen op deze wijze kunnen worden getypeerd. 30 beroepsklassen bieden goede arbeidsmarktperspectieven, 16 daarvan zijn bovendien weinig conjunctuurgevoelig, terwijl er ook uitwijkmogelijkheden naar andere sectoren bestaan. Voor 10 beroepsklassen zijn de middellange-termijn perspectieven goed te noemen, maar is de werkgelegenheid wel erg conjunctuurgevoelig.

Daarentegen bieden 13 beroepen matige en 8 beroepen slechte arbeidsmarktperspectieven. Onder de beroepen met matige perspectieven bevinden zich enkele hooggeschoolde specifiek kwartaire beroepsklassen, maar ook de beroepsklasse beleidvoerende en hogere leidinggevende functies (exclusief openbaar bestuur). 
Schema I: Typering perspectieven van beroepsklassen

1. Goed werkgelegenheidsperspectief, weinig conjunctuurgevoelig en bovendien bestaan er uitwijkmogelijkheden.

Wiskundigen, systeemanalisten, e.d.*

Economen

Accountants*

Juristen (GS)

Secretaressen en typisten*

Computerapparatuur-operateurs e.d.

Post- distributiepersoneel (GS)

Telefonisten, telegrafisten e.d.

Toezichthoudend- en leidinggevend commercieel personeel

Winkelbedienden

Vertegenwoordigers e.d.

Directeuren en bedrijfsleider horecabedrijven

Huisbewaarders en schoonmaakpersoneel

Dienstverlenende functies n.e.g.

Bedrijfsleiders land- en tuinbouw (GS)

Instrumentmakers, monteurs, e.d.

2. Goed werkgelegenheidsperspectief, weinig conjunctuurgevoelig, maar er zijn ook weinig uitwijkmogelijkheden.

Beleidsvoerende en hoger leidinggevende functies bij

openbaar bestuur* (GS)

Uitvoerende hoofdambtenaren ${ }^{*}$

Conducteurs, trein, bus, e.d.

Zelfstandige groothandelaren en tussenpersonen

3. Goed werkgelegenheidsperspectief maar erg conjunctuurgevoelig. Er zijn uitwijkmogelijkheden.

Mijn-, groeve-arbeiders, bronboorders, e.d.

Houtzagers, papiermakers, e.d.

Chemische procesarbeiders

Spinners, wevers, ververs, e.d.

Meubelmakers e.a. houtbewerkers

Smeden, gereedschapmakers, machinale metaalbewerkers

Loodgieters, pijpfitters, lassers, plaat- en constructiewerkers

Rubber- en plasticproduktenmakers (GS)

Schilders e.d.

Ambachts- en industrieberoepen n.e.g. (GS)

Metselaars, timmerlieden e.a. bouwvakarbeiders

Dokwerkers, sjouwers, reinigingsambtenaren, e.d.

4. Goed werkgelegenheidsperspectief, maar erg conjunctuurgevoelig en weinig uitwijkmogelijkheden 
5. Redelijk werkgelegenheidsperspectief, weinig conjunctuurgevoelig en er zijn ook uitwijkmogelijkheden

Schei-, natuurkundigen en vẹxwante technici ${ }^{*}$

Ingenieurs, tekenaars, e.d.

Biologen, biochemici, landbouwkundigen e.d.

Genees- en verpleegkundigen, e.d.

Beeldhouwers, kunstschilders, fotografen e.a. beeldende

kunstenaars

Toezichthoudend en leidinggevend administratief personeel(GS)

Bankemployes, lokettisten, e.d.

Toezichthoudend- en leidinggevend transport- en communicatie

personeel (GS)

Diverse administratieve functies

Toezichthoudend- en leidinggevend huishoudelijk personeel

e.d. (GS)

Koks, kelners, e.d.

Brandweer-. politiepersonee 1, bewakers e.d.

Boswachters, bosarbeiders, e.d.

Machinisten e.a. bedieners van stationaire machines en

installaties

Laders, lossers, inpakkers, e.d.

Chauffeurs, matrozen, treinbestuurders e.d.

6. Redelijk werkgelegenheidsperspectief, weinig conjunctuurgevoelig, maar er zijn ook weinig uitwijkmogelijkheden.

Directeuren en bedrijfsleiders groothandel* (GS)

Directeuren en bedrijfsleiders detailhandel (GS)

Zelfstandige hotel-, caféhouders, e.d.

kappers, schoonheidsspecialisten,e.d.

7. Redelijk werkgelegenheidsperspectief, maar erg conjunctuurgevoelig. Er zijn echter uitwijkmogelijkheden.

Hoogovenarbeiders, walsers, gieters, e.d.

Leerlooiers, pelsbereiders e.d. (GS)

Schoenmakers en lederwarenmakers

Elektromonteurs en -reparateurs

Glas- en aardewerkvormers, e.d.

Drukkers e.d.

8. Redelijk werkgelegenheidsperspectief, maar erg conjunctuurgevoelig en weinig uitwijkmogelijkheden. 
9. Matig werkgelegenheidsperspectief, weinig conjunctuurgevoelig en er zijn ook uitwijkmogelijkheden.

Auteurs, journalisten, e.d.* (GS)

Sociale hulpverleners, vertalers, e.d.* (GS)

Beleidvoerende en hogere leidinggevende functies (exclusief

openbaar bestuur) (GS)

Verzekeringsagenten, makelaars e.d.

Huishoudelijk en verzorgend personeel

Voedingsmiddelen- en drankenbereiders

Radio- en TV-, geluids-, beeldapparatuurbedieners (GS)

10. Matig werkgelegenheidsperspectief, weinig conjunctuurgevoelig, maar er zijn ook weinig uitwijkmogelijkheden.

Leerkrachten ${ }^{\star}$

Zelfstandige detailhandelaren

Agrarische arbeiders

11. Matig werkgelegenheidsperspectief en bovendien erg conjunctuur gevoelig. Er zijn echter uitwijkmogelijkheden.

Diverse commerciële functies

Toezichthoudend, leidinggevend produktiepersoneel (GS)

Kleermakers, stoffeerders, e.d.

12. Matig werkgelegenheidsperspectief en bovendien erg conjunctuurgevoelig en weinig uitwijkmogelijkheden.

geen

13. Slecht werkgelegenheidsperspectief, weinig conjunctuurgevoelig en er zijn ook uitwijkmogelijkheden.

Vliegtuig- en scheepsofficieren

Musici, toneelspelers e.a. uitvoerende kunstenaars (GS)

Grond- en zilversmeden, diamantbewerkers e.d.

14. Slecht werkgelegenheidsperspectief, weinig conjunctuurgevoelig, maar er zijn ook weinig uitwijkmogelijkheden.

Bedienaars van een eredienst, e.d.*

Zelfstandige land- en tuinbouwers

Vissers, e.d. (GS)

Tabaksproduktenmakers (GS) 
15. Slecht werkgelegenheidsperspectief en bovendien erg conjunctuurgevoelig. Er zijn echter uitwijkmogelijkheden.

geen

16. Slecht werkgelegenheidsperspectief en bovendien erg conjunctuurgevoelig en weinig uitwijkmogelijkheden.

Steenhouwer, -zagers, slijpers e.d. (GS)

Papierwaren- en kartonwerkers

(GS) = geen directe instroom voor schoolverlaters verwacht

* $\quad$ = beroepsklasse waarin minimaal 1000 academici werkzaam zijn 


\subsection{Perspectieven van academische studierichtingen}

Voor de 12 onderzochte studierichtingen in het Wetenschappelijk Onderwijs is het mogelijk de prognoses van de totale vraag naar nieuwkomers te combineren met de prognoses van de instroom van afstuderenden in de periode 1985 - ' 92.

Dit leidt tot de in paragraaf 4.1 afgeleide arbeidsmarktperspectieven voor de verschillende studierichtingen. Daarnaast zal worden gekeken naar de beroepenspreiding van de studierichtingen.

De typering van de academische studierichtingen is op de volgende classificatie gebaseerd:

\section{Arbeidsmarktindicator (AMI)}

AMI $\leq 1$ goed arbeidsmarktperspectief

$1<A M I \leq 2$ redelijk arbeidsmarktperspectief

$2<A M I \leq 4$ matig arbeidsmartkperspectief

$4<$ AMI $\leq 8$ slecht arbeidsmarktperspectief

AMI $>8$ erg slecht arbeidsmarktperspectief

\section{Beroepenspreiding (GH)}

$0,7 \leq \mathrm{GH} \leq 1,0$ veel uitwijkmogelijkheden

$0,3<\mathrm{GH}<0,7 \quad$ enige uitwijkmogelijkheden

$\mathrm{GH} \leq 0,3$ weinig uitwijkmogelijkheden

Schema II geeft een overzicht van de wijze waarop de verschillende studierichtingen kunnen worden getypeerd. Alleen voor de studies theologie en technische wetenschappen zijn de arbeidsmarktvoorspellingen gunstig. Met name voor de studie theologie is dit opvallend, temeer daar voor de beroepsklasse 'bedienaars van de eredienst, e.d.', waar veel afgestudeerde theologen in terecht komen, geen enkele werkgelegenheidsgroei wordt verwacht. Deze discrepantie wordt door twee factoren veroorzaakt. In de eerste plaats is de vervangingsvraag bij theologie erg hoog en in de tweede plaats is er bij theologie sprake van een relatief geringe instroom van afstuderenden in de beroepsbevolking. Deze factoren wijzen er op dat het niet toereikend is arbeidsmarktprognoses te beperken tot alleen werkgelegenheidsprognoses. 
Voor de meeste studierichtingen zijn de arbeidsmarktverwachtingen op de middelllange termijn weinig rooskleurig. Dit ondanks de verwachte omvangrijke groei van de werkgelegenheid voor academisch geschoolden: $27 \%$, t.0.v. een groei van de totale werkgelegenheid van ca. $10 \%$. De oorzaak hiervan is de enorme toename van de instroom van afstuderenden in de meeste studierichtingen. Voor een deel is dit het gevolg van de dubbele uitstroom van oude en nieuwe stijl afgestudeerden in het begin van de door ons onderzochte periode. Daarnaast gaat het om een voortzetting van de trendmatige groei van het aandeel jongeren dat een universitaire opleiding volgt, mogelijk versterkt doordat er meer jongeren doorstuderen als gevolg van de slechte arbeidsmarktsituatie in de jaren ' 80 . Alleen bij de studierichtingen theologie, technische wetenschappen en medische opleidingen is de instroom van afstuderenden in de arbeidsmarkt wat minder omvangrijk.

Met uitzondering van de medische opleidingen bestaan er bij vrijwel alle studierichtingen uitwijkmogelijkheden naar verschillende beroepsklassen. Het is waarschijnlijk dat bij een hoge werkloosheid onder afgestudeerden in een bepaalde studierichting, de afstuderenden meer dan in onze voorspelingen is geraamd van deze uitwijkmogelijkheden gebruik zullen maken. Daarbij moet wel bedacht worden dat het hier niet hoeft te gaan om alternatieven die aansluiten bij de genoten opleiding. Dit blijkt het duidelijkst bij de kunstopleidingen, waar nogal wat afgestudeerden een baan vinden buiten de kunst- of onderwijsberoepen. 
Schema II: Typering perspectieven academische studierichtingen

\section{Studierichting}

- Theologie Technische wetenschappen

- Econometrie, Actuariaat en bedrijfskunde (ir.)

- Rechten

Wis- en natuurkunde Economische wetenschappen en bedrijfskunde (drs.)

- Sociaal-culturele wetenschappen

- Medische opleidingen

- Agrarische wetenschappen en huishoudkunde

- Letteren Farmacologie

- Kunstonderwijs

\section{Typering}

Goed arbeidsmarktperspectief en bovendien enige uitwijkmogelijkheden

Redelijk arbeidsmarktperspectief en bovendien veel uitwijkmogelijkheden

Matig arbeidsmarktperspectief met veel uitwijkmogelijkheden

Matig arbeidsmarktperspectief met enige uitwijkmogelijkheden

Matig arbeidsmarktperspectief met weinig uitwijkmogelijkheden

Matig arbeidsmarktperspectief en met veel uitwijkmogelijkheden

Slecht arbeidsmarktperspectief met enige uitwijkmogelijkheden

Erg slecht arbeidsmarktperspectief met veel uitwijkmogelijkheden 



\section{BESLUIT}

Zoals in de verantwoording reeds werd opgemerkt is deze discussienota bedoeld als een eerste versie van het ROA-informatie-systeem onderwijsarbeidsmarkt. Een belangrijke tekortkoming is ons inziens dat vooralsnog prognoses moesten worden gemaakt voor beroepsklassen en studierichtingen, die vaak sterk verschillen van de feitelijke arbeidsmarktsegmenten voor de verschillende beroepen en opleidingen. De aanpak van dit probleem vereist een andere aggregatie van beroepen dan die in de beroepenclassificatie van het CBS. Een verdergaande desaggregatie naar opleidingsrichting was helaas evenmin nog niet mogelijk.

Vanzelfsprekend vormen de macro- en meso-economische prognoses, die als basis hebben gediend voor onze beroepen- en opleidingsprognoses, een mogelijk belangrijke bron van onzekerheid. Deze economische prognoses zijn immers noodzakelijkerwijze gebaseerd op een aantal veronderstellingen, met name met betrekking tot de ontwikkeling van de internationale concurrentiepositie van het bedrijfsleven.

De verdeelmodellen op basis waarvan de prognoses voor beroepsklassen en academische studierichtingen zijn gemaakt, zijn in tegenstelling tot eerdere prognose-studies, theoretisch onderbouwd door een tweetal hypotheses, respectievelijk vanuit een verdringings- en een 'upgradings'optiek. Helaas kon er ten aanzien van het verdringingsproces nog geen rekening worden gehouden met het 'push'-effect van verschuivingen in de opleidingsstructuur van het arbeidsaanbod.

Het ontbreken van deze push-factor in het verdringingsproces op de arbeidsmarkt impliceert dat in onze prognoses van de arbeidsmarktsituatie naar opleidingsrichting, onvoldoende rekening is gehouden met de verdringing die de komende jaren naar alle waarschijnlijkheid zal optreden als gevolg van het vrij explosief stijgende aantal afstuderenden in verschillende universitaire studierichtingen. Mede daarom wordt in ons onderzoek ook geen voorspelling gemaakt van de toekomstige werkloosheidspercentages in de diverse studierichtingen. Dit betekent echter niet dat de arbeidsmarktperspectieven voor de meeste studierichtingen veel rooskleuriger zullen zijn dan in deze studie is voorspeld. Bij een groot aantal studierichtingen zal de opname van universitair geschoolden op de arbeidsmarkt waarschijnlijk niet probleemloos verlopen (zie schema II). 
Literatuur

Beke, J.M.J. op de, (1987), Herziening trendmatig arbeidsaanbod 19852000, interne notitie CPB no II.10, 's Gravenhage.

Blaug, M., (1967), Approaches to Educational Planning, Economic Journal, p. 262-287.

Centraal Planbureau, (1986), Centraal Economisch Plan 1986, Staatsuitgeverij, 's-Gravenhage.

Centraal Planbureau, (1987-I), Centraal Economisch Plan 1987, Staatsuitgeverij, 's-Gravenhage.

Centraal Planbureau, (1987-II), De arbeidsmarkt naar opleidingscategorie 1975-2000, W17, 's-Gravenhage

Grip, A. de, (1984), Arbeidsmarktverwachtingen en de keuze voor de economiestudie, Economisch Statische Berichten, p. 1094-1101.

Grip, A. de, (1987), Onderwijs en Arbeidsmarkt: Scholingsdiscrepanties, VU-uitgeverij, Amsterdam.

Grip, A. de, L.F.M. Groot en J.A.M. Heijke, (1987), Clustering Occupational Classes by Educational Structure, ROA-W-1987/2E, Maastricht.

Grip, A. de, J.A.M. Heijke, R.J.P. Dekker, L.F.M. Groot en L.A. Vos, (1987), De arbeidmarktperspectieven van studierichtingen in het Wetenschappelijk Onderwijs 1992, - Arbeidsmarktmodule I-SEE project, ROA-R-1987/3, Maastricht.

Hollister, R.G., (1965), A Technical Evaluation of the First Stage of the Mediterranean Regional Project, OECD, Paris.

Hoof, J.J. van, J. Dronkers (1980), Onderwijs en arbeidsmarkt; een verkenning van de relaties tussen onderwijs, arbeidsmarkt en arbeidssysteem, Van Loghum Slaterus, Deventer. 
Kodde, D.A., (1984), Wie kiest er voor hoger onderwijs?, Tussenverslag van project "de vraag naar hoger onderwijs", Katholieke Universiteit Nijmegen, RMi7 8401, Nijmegen.

Ministerje van Sociale Zaken en Werkgeiegenheid, (1987), Rapportage arbeidsmarkt 1987. 's-Gravenhage.

Nederlands Econornisch instituut, (1972), Bouwnijverheid: planning, groei en fiuctuaties, deei II: fluctuaties, Rotterdam.

Rederlards Economisci Instituut, (1986), Een verkenning van de arbeidsmarke naar beroep en opleiding, OSA-werkdorument nr. W17, 'sGravenhage.

ROA, (1987), Naar een informatiesysteem ond zrwijs-arbeidsmarkt, onderzoekprogramma 1987/1988, ROA-R-1987/2, Maastricht.

Taakgroep Studentenramingen, (1986-I), Wetenschappelijk Onderwijs Ramingen Studenten Aantallen 1986-2000 (WORSA), 's-Gravenhage.

Taakgroep Studentenramingen (1986-II), Raming Hoger Beroepsonderwijs Studentenaantallen 1986-2000 (RHOBOS), 's-Gravenhage.

Warnken, J.,(1986), Zur Entwickelung der "Internen" Anpassungfähigkeit der Berufe bis zum Jahre 2000. Projektionen unter den Annahmen der Wachstumzenarien der Prognos-Studie, Mitteilungen aus der Arbeitsmarktund Berufsforschung, no 1, blz. 119-133.

Youdi, J., K. Hinchcliffe (eds.), (1985), Forecasting Skilled Manpower Requirements: The Experience of Eleven Countries, UNESCO, Paris. 